\title{
THE CHANGING ROLE OF KNOWLEDGE PROFESSIONALS AS ATOOL OF INNOVATION: THEORETICAL AND PRACTICAL PERSPECTIVES
}

\author{
Berat Bir, Melisa Erdilek Karabay, Bahattin Yalçınkaya \\ Associate Professor, ph.d., Marmara University \\ beratbir@marmara.edu.tr \\ Ph,d. , Marmara University \\ merdilek@marmara.edu.tr \\ Ph,d. , Marmara University \\ yalcinkaya@marmara.edu.tr
}

\begin{abstract}
Advances and applications in the business environment posed by the digital-age enforce the organizations to renew their strategies and improve their innovative capabilities. Today, the major actors of the knowledge economy are the knowledge professionals. This studv aims to provide a comprehensive outlook at the innovation phenomenon within the essential components of Knowledge Management. In this regard, innovation in organizations is discussed within the perspective of knowledge management whereas the importance of knowledge assets in the process of innovation is explained through knowledge professionals. Furthermore, the study contributes to the knowledge management literature by presenting theoretical and practical implications of innovation by examining the latest practices on public services in Turkey.
\end{abstract}

\section{Keywords}

Knowledge Management, Knowledge Assets, Innovation, Knowledge Professionals, E-governance.

\section{Academic Discipline And Sub-Disciplines}

Knowledge Management, Egovernance, Corporate Strategy, Competition Theory, Strategic Management.

\section{SUBJECT CLASSIFICATION}

E.g., Mathematics Subject Classification; Library of Congress Classification

\section{TYPE (METHOD/APPROACH)}

Research Article

\section{Council for Innovative Research}

Peer Review Research Publishing System

Journal: Journal of Social Sciences Research

Vol. 8 , No. 3

jssreditor.cir@gmail.com

www.jssronline.com 


\section{Introduction}

Innovation emerges as an important factor that determines the value of knowledge as an asset. Today, it is used strategically by organizations. It is well understood that the most important resources which corporations search for consist of "knowledge". Corporations can obtain competitive advantages through their knowledge management applications only if they can innovate from their knowledge assets. This conversion is possible with the active usage of information technology tools. Knowledge management systems refer to a class of information systems (IS) applied to managing organization knowledge, which is an IT-based system that supports the organizational knowledge management behavior.[1]

Knowledge measurement is closely associated with information technologies. It also emphasizes the importance of integrating organizational core knowledge, both tacit and explicit, with an adequate IT infrastructure. Developments in technology all organizations to benefit from knowledge management applications. Despite the fact that knowledge and knowledge management have gained strategic importance with the influence of qlobalization, most conorations still have considerable trouble with revealing corporate knowledge. For corporations to become a part of the "Knowledge Society", their business processes must become knowledge and technology-oriented. Therefore, during this process, it is important that the organizations believe that their management approaches, as well as their comorate culture, are based on using, sharing, and evaluating knowledge. In this respect, there needs to be a management culture equipped with skilled professionals who can use knowledge efficiently.[2]

It is also critical the knowledge within the organization.Organizations can measure the return on investment by measuring the intellectual value of knowledge assets created by knowledge workers. Since the source of value is considered as knowledge, it can become an important gain for organizations when used efficiently by knowledge professionals .[3] Therefore, organizations need to understand that the most valuable elements are human beings. For this, organizations began to focus more on developing knowledge management philosophy that is supported by innovation .[3]

Knowledge professionals have the ability to act more effectively than the most advanced machines. They are also much capable of synthesizing and rapidly transforming problems into solutions. In this respect, this makes them the most critical actors in innovation process.

In this study, the emerging role of knowledge professionals in the construction of today's knowledge era is examined from an innovation perspective. The increasing role of innovating in knowledge management is discuss ed by outlining the latest regulations and developments in the field, like governance and e-governance, particularly in Turkey. The rest of the chapter proceeds as follows: In the first section, the theoretical background of knowledge management and its components are briefly explained. Next, the theoretical components of innovation are discussed on the basis of different types of innovation. The association between knowledge management and innovation is highlighted through recent developments in public services in Turkey. The final section includes further discussion and recommendations.

\section{The Fundamentals of Knowledge Management}

The transition process to knowledge economy leads to a mandatory change in the fields of economic activities from production to marketing. Putting the traditional factors of production aside, it can be said that knowledge is becoming the most important source of competition. Thus, in order to compete in the knowledge economy, it is extremely important for corporations to recognize knowledge and information as an intellectual asset.[4] Mostly facilitated by American organizations, the new developing economic wave forces individuals, corporations and nations to reconstruct through a new global identity. In this new formation, tough times are expected for corporations which continue to operate in the traditional sense. Organizations that resist to change and stay true to their traditional structure run the risk of losing their competitive power.[5]

Knowledge management appears as a competitive strategy, yet it has to be followed throughout, from the upper levels of management to the front line worker. Organizations must hold its employees accountable for capturing, managing, storing, sharing, preserving and delivering information appropriately and responsibly. Part of that responsibility lies in developing the organizations to become familiar with the policies, processes, technologies and best practices in KM.

\subsection{Characteristics of Knowledge}

Widely known as information [6]knowledge is an idiosyncratic concept $[7\rceil$ and has been defined as the transformation of both information and data to useful applications that will bring economic growth to corporations.[8] However, in the knowledge-based economic formation, for corporations to benefit from knowledge rationally, they need to identify their knowledge assets. Knowledge has some fundamental characteristics that distinguish it from other factors of production such as:

- Knowledge is a dynamic social process. It is open to change and development. When used, it becomes valuable and it demonstrates growth when shared.[9]

- Knowledge has a profit characteristic dependent on a scale. If the user network is wide, the usage of it increases.[10]

- Knowledge is comprehensive. It cannot be digitized like material, such as land or stock. The value of knowledge is measured by the relationship between the user.[11]

- Unlike standard economic objects, knowledge is hard to purchase. Thus, there is an asymmetrical issue about what the seller sells and what the buyer buys.[12] 
- Knowledge has to be accessible. This means it is protected by laws and regulations which make knowledge securely accessible to everyone. Knowledge has to be accessible through organizations which can enable better flow of knowledge.

- Knowledge needs to be reliable and qualified. Therefore, it should be comprehensible, complete and demonstrate permanency.

- Basic standards need to be created about the quality of knowledge. The most basic method for providing security is to inspect if the standards are followed or not. This should be done by the international organizations, inspectors or the institutions that create the standards.[13]

\subsection{Types of Knowledge}

Knowledge is extremely important for the economic cycle, since it contributes to productivity. Nevertheless, all information in general is not considered to be a knowledge itself and consdered as an asset. It could be more efficient for organizations when types of knowledge and their characteristics are well-known. Organizations may decide whether information is a knowledge asset according to their commercial purposes. In the literature, it is mentioned that knowledge is divided into two groups; explicit and tacit .[14]

a. Explic it Knowledge: Explicit knowledge consists of words or numbers. For this reason, it can be easily obtained by orqanizations. Explicit knowledge is accessible by any orqanization.[15][16] Accordingly, explicit knowledge is a knowledge that is collected, stored, distributed and shared as primarily electronic or paper documents. Thus, explicit knowledge contains easily transmitted, documented and transferred knowledge and abilities .[17]

b. Tacit Knowledge: Tacit knowledge is rather harder to access, as it is more private than explicit knowledge.[18] It is comprehended and practiced subconsciously. Consequently, such knowledge is acquired directly from experiences and actions, as it is hard to be clearly expressed .[19]Tacit knowledge is described as a subjective type of knowledge which cannot be expressed in sentences.[17]

By obtaining and sharing explicit and tacit knowledge, organizations demonstrate improvement not only in organizational sense, but also in terms of individual performance and attitude, leading to greater innovative performance.[20] Therefore, identifying knowledge types is vital for the identification and conceptualization of efforts.

According to this, while tangible assets can be counted in explicit knowledge-oriented organizations, partially tangible assets stand out in tacit knowledge-oriented organizations. Technical and cognitive elements are also centered in tacit knowledge.

The general philosophy of organizations are also critical in this process. An understanding of the strategic perspective of innovation-management and knowledge-management applications play important role to obtain a competitive advantage. Knowledge has the potential to connect strategies and provide greater competition advantage. Therefore, to be able to compete, organizations need to develop knowledge-based competitive strategies. These strategies should be flexible enough to adapt to the changing conditions of the business environment.[21] To achieve better results from innovative efforts, a competitive strategic management approach must be implemented by corporations. Furthermore, it is important that knowledge be used effectively to encourage innovation within the organization, since this will help to maintain a competitive edge.[3]

Organizations enter into collaborations to take advantage of partners' knowledge and strengths, since these collaborations are assumed to encourage the transfer of codified and tacit knowledge from one fim to another.[116][23]

\section{Innovation and Knowledge Management}

Innovation is a key success factor in competition today. Despite various views most researchers define innovation as the new ideas, methods or tools in organizations that reveal something new .[2] and something that the competitors have not done yet. With the rapid evolving information age, corporations have begun to take steps in generating knowledge activities. The primary expectation of organizations is to have better quality and a more innovative perspective for the creation of new knowledge, not only for products, but also for services and customer relations.

Literature highlights insights with regard to knowledge and innovation [24] [25] [26] [27] [28]emphasize that creating organizational knowledge is necessary in order to be innovative by corporate learning. Innovation researchers have argued that innovations often result from combining existing pieces of knowledge. [29] [30] Having a diverse knowledge base within the firm can facilitate innovation through combinations of accessible knowledge.[22]

\subsection{Types of Innovation}

In the literature, the main types of innovation are described as below [31]:

\subsubsection{Product Innovation}

This type of innovation involves changes in the products or services that an organization offe rs [32] [331 This is recognized as the engine of corporate renewal. [34] [35] The literature states that product innovation functions as a tool for organizational learning, and contributes to fim renewal.Various studies claim that managers believe that tech nological advancement increases the value of the service product innovation to customers.[23] Product innovation requires producing "really new" products, because these are essential to the corporation's survival in the rapidly changing market. 
New product development requires bringing together two competences, such as the competence relating to technology and the other competence relating to customers. Each of these competences is constituted by a set of resources .[36] Bonanno and Haworth (1998), in their study, state that product innovation is an improvement in the quality of a firm's product. [37] Organizations that develop effective knowledge management (KM) strategies for knowledge integration can serve as models, leading to consistent product innovations. [23]

\subsubsection{Technological Innovation}

The growth of knowledge intensive sectors and their share in global commerce are highly dependent on knowledge and communication technologies (ICT), as these hold a strategic importance in business. .51 This type of innovation is related to both technological product/service and the process [38] Technological innovation of products can either be a new product that has been technologically improved or a product that is technologically introduced.[39] Technological competence gives a company the ability to design and manufacture a physical product with certain features. This is constituted by technically related resources such as: design and engineering know-how, product and process design equipment, manufacturing facilities and procedures for quality control.[36]

\subsubsection{Process Innovation}

Process innovation is defined as newly or significantly improved implementation of the method of production or distribution. [33] [32] Process innovation comprises a wide variety of technical, product, process, and administrative innovations. [40] Although innovation is assumed to be fundamental in manufacturing fims, product innovation plays a more important role in particular sectors [38] Process innovations are concerned with the innovative act on the whole or any steps to be carried out in the development or creation of products/services rather than whole products . [41] Therefore, process innovation cannot be diminished to the use of technical systems in the process of producing a s ervice. It is particularly pertinent to the introduction of information systems, as well as telecommunications systems, and the perfection of expert systems and methodologies [42]

\subsubsection{Organizational Innovation}

This type of innovation is concerned with new embodiments that gather human and material resources in the most optimal way. [41] Organizational innovation is non-technological innovation, but is at least as important as technological innovation. It is important that the sustainability of competitiveness image and reputation are present as the drivers of organizational innovation.[33]

Whether product, process, organizational or technological based, innovation represents today's competitive advantage. It needs to be supported by strong ability in quality, efficiency, speed and flexibility. Where there is great competition, highperforming innovators need to maintain a strategic capability and bring high quality products to the market more rapidly, more frequently and at a lower cost than their competitors. Innovation can help comorations play a dominant role in shaping the future of industries. Moreover, these fims have to use process and systems innovation as a way of improving their products and adding value for customers. This combination may create a dynamic and sustainable strategic position, which in the long term, allows the organization to have a sustainable competitive advantage [43] [44]

\subsection{The Importance of Knowledge in Innovation Process}

For decades, old-economy corporations have often been tangible-asset oriented. Their production output was also considered as tangible [45]. But, in the new economic order, corporations need to check their competitive strategies to understand how their knowledge will create long-term value.[46] Core competences of an organization are extremely important for the survival of organizations in business. Without a knowledge management philosophy in an organization, these competencies may be difficult to attain. Thus, as mentioned previously, it becomes easier to understand why "Knowledge Management" is critical for them.[3]

Looking at the history of knowledge management, the innovation wave had bequn by 1995. From today, advances in research and innovation, knowledge and skilled labor have gained more importance.[47] In the new economy order, copying or releasing a similar product is not costly. This causes a major challenge for corporations in determining product price. Thus, corporations aim that their prices be above the marginal cost and that they compensate for the fixed costs spent in development of the product with income from sales. [48]

Innovation consists of various stages. These stages have different orders and qualities which can often be changed. Corporations develop an innovation strategy according to their expectations from the innovation. The development process of innovative strategies is similar to the development process of managerial strategies, as the corporation's basic strategies and innovation strategies are dependent on one another. [49] In particular, after discovering the needs of the clients, sometimes a new product is required and launched on the market or product differentiation may be used in competition. Knowledge has power for corporations that are in need of this advantage, since a greater competition and collaboration between users can be created by knowledge. 
Table 1. Various Implications of Knowledge Management and Innovation Configuration

\begin{tabular}{|c|c|c|}
\hline Authors & Aims and Scope & Implications\& Findings \\
\hline Du Plessis (2007) [50] & $\begin{array}{l}\text { Clarification of the role of knowledge } \\
\text { management in innovation while } \\
\text { seeking to identify the drivers for } \\
\text { application of knowledge } \\
\text { management in innovation. }\end{array}$ & $\begin{array}{l}\text { - Making explicit knowledge available for } \\
\text { recombinations into new and innovative ideas. } \\
\text { - Provides the tools, processes and platforms to } \\
\text { ensure knowledge availability and accessibility, } \\
\text { - KM can ensure that explicit knowledge, which can } \\
\text { be used as input to the innovation process, } \\
\text { gathered internally and externally. }\end{array}$ \\
\hline Darroch (2005) [51] & 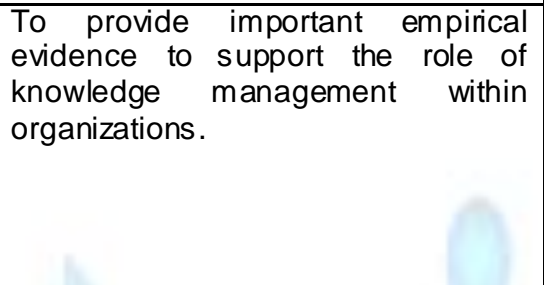 & $\begin{array}{l}\text { - Firms with a propensity toward developing } \\
\text { incremental innovations are considered to have } \\
\text { well-developed knowledge management } \\
\text { behaviours and practices. } \\
\text { - Firm with a knowledge management capability may } \\
\text { use resources more efficiently and so will be more } \\
\text { innovative and perform better. }\end{array}$ \\
\hline Anand et al., (2007) [52] & $\begin{array}{l}\text { To provide accurate view of how } \\
\text { innovative knowledge-based } \\
\text { structures emerge and become } \\
\text { embedded in organizations. }\end{array}$ & $\begin{array}{l}\text { - Socialized agency, differentiated expertise, } \\
\text { defensible turf and organizational support must be } \\
\text { linked in specific pathways for knowledge-based } \\
\text { innovative structures. }\end{array}$ \\
\hline Zhang et al.,(2010) [53] & $\begin{array}{l}\text { To investigate how knowledge } \\
\text { acquired from alliance partners } \\
\text { influences organizational knowledge } \\
\text { creation, that in turn leads to } \\
\text { innovative performance. Knowledge- } \\
\text { innovation relationship is proposed } \\
\text { to be stronger in intemational } \\
\text { alliances than domestic alliances. }\end{array}$ & $\begin{array}{l}\text { - The more scarce and the more difficult to acquire } \\
\text { knowledge is, the more likely firms will apply it in } \\
\text { the innovation process. } \\
\text { - Knowledge acquired in intemational alliances is } \\
\text { applied more to innovation than knowledge } \\
\text { acquired in domestic alliances. }\end{array}$ \\
\hline $\begin{array}{l}\text { Vaz and Nijkamp (2009) } \\
\text { [54] }\end{array}$ & $\begin{array}{l}\text { Several concepts related to } \\
\text { innovation and knowledge are } \\
\text { evaluated to justify that knowledge } \\
\text { based innovation is a tool to reach } \\
\text { sustainable growth. }\end{array}$ & $\begin{array}{l}\text { Knowledge is recognized as primary key resource } \\
\text { for firms and other economic agents, while both } \\
\text { codified knowledge and tacit knowledge are } \\
\text { pertinent aspects for innovation. }\end{array}$ \\
\hline Brusoni et al., (2005) [55] & $\begin{array}{l}\text { An empirical exploration of the use of } \\
\text { codified sources of infomation for } \\
\text { innovation at the fim and sectoral } \\
\text { level is provided. }\end{array}$ & $\begin{array}{l}\text { - Attempts to improve the distribution power of the } \\
\text { innovation system by supporting codification } \\
\text { exercises (for instance; computer-information } \\
\text { networks) will have a limited impact on overall } \\
\text { rates of innovation. } \\
\text { - Few industries rely on patent disclosure and } \\
\text { computer-based information networks to innovate. } \\
\text { - Expanding the use of codified knowledge may } \\
\text { increase the importance of other parts of the } \\
\text { innovation system. }\end{array}$ \\
\hline
\end{tabular}

As summarized in Table 1, literature sets back with various studies highlighting the association of knowledge and innovation. Despite these implications it can be stated that there is still lack of evidence which reveals different evolution of knowledge playing in the role of innovation process. Innovation can be developed in two ways. One is to carry out in-depth research and create new knowledge. The way to create knowledge is through research and development (R\&D). The basic characteristic of countries and corporations that are successful in technology is that they often invest in R\&D. At this stage, they also invest in human resources by employing and training scientists and engineers. The other way to develop innovation is to ensure that the innovation is inspired by innovation in other areas. [56]

\subsubsection{Knowledge as an Asset}

In the knowledge economy, corporations may choose to invest in knowledge and manpower rather than in tangible assets. Many manufacturing corporations that are considered to among the leading corporations prefer such a strategy to increase their market share. Similarly, large comorations choose to leave their production activities to outsourcing corporations [45]. Resource-based theory for the most part concentrates on the increase in company resources which can 
act as a sustainable source of competitive advantage. According to this approach, company resources consist of tangible and intangible values, individuals or non-individual assets which allow creating and practicing the strategies that company has control. [571 For this reason, company values are based on long-term scientific knowledge and intellectual stock. Intellectual assets are for the most part the intellectual property, patents, registration rights, trade secrets, financial records, strategies, relations and other intangible assets of the organization. [58] [4] These intangible assets include the tacit knowledge as tacit knowledge involves not only ability, expertise and vision, but also experiences and relationships. Even if tacit knowledge is ignored most of the time, it creates a competitive advantage for many corporations in the market. [59]

Intangible assets, are considered as the future support of sustainable competitive advantage. This is especially valid for knowledge-based industries, such as knowledge and software services. Consequently, competitive advantage depends on "the know-how knowledge shaped by human". According to this, it is not physical capital or financial capital, but human capital which creates market leaders. Thus, the strategic management of intellectual capital becomes more important than ever. [19]

The literature reveals similar evidence to the assumptions highlighted above with regard to the emerging importance of knowledge. In their study, [4] investigated the efficient usage of knowledge management systems in Turkish financial sector. According to the empirical results, the banking industry is not well-informed about the measurement of knowledgebased assets. On the other hand, the authors also implied that the importance given to the financial value of knowledge is also unsatisfactory as compared to other service industries. Accordina to Jordan, considering its strategic importance, the value of intellectual assets is generally hidden, as they do not appear on financial statements. [60] In his study, Sharkie (2003) claimed that it is only possible to demonstrate the effect of knowledge as a strategic competitive to ol if it has been advanced in the organizational structure of the core business competencies.[61] On the other hand, creating knowledge strategies by analyzing strategic knowledge gaps is critical. Kridan and Goulding (2006) emphasized the possibility of being successful only if the business management has a proper knowledge management strategy. [62] In their study, Chan and $\mathrm{Au}$ (2008) stated that if knowledge is recognized as a strategic asset, forward-looking businesses may be aware that knowledge management has a great deal to offer. [63] They also stated that comorations need to share, obtain, store and publish in order to sustain long-tem competitiveness in these assets against their competitors. DeTienne and Jackson (2001) argued that knowledge management has become the latest strategy for increasing organizational competitiveness.[201 Jordan (1997) claimed that knowledge manaqement has emerged as a major theme in management literature, where it is stated that it plays the role of building and sustaining the competitive advantage. [60] According to Jordan, this huge increase on KM emerges from the increasing intensity of competition, which in turn is a response to the rapid rate of technological change. Hamel and Prahalad (1990) investigated intangible assets related to the company's key competencies. [64] They claimed that these assets, in contrast to physical assets, are the source of development because of their increasing profit characteristics.

In addition to the different studies summanized above, the dynamics of organizations are explained by Neoclassical, Penrosian and Schumpeterian approaches. In Neoclassical approach, there is no effort to concentrate on production technology, competitive strategies, organization or the dynamics of the capitalist system. [65] In the Schumpeterian approach, with the theory of general equilibrium price being put to one side, entrepreneurs and innovation come to the fore. However, the Schumpeterian approach is not interested only in the organization of the company. According to the Schumpeterian approach, an entrepreneur is not someone who brings together the factors of production nor does he offer capital to the market by taking risks. Factors of production are gathered in a new way, by placing new goods and new production techniques. By the exploration of new markets; in short, innovations are effective on internal dynamics of the business growth of the company as supported by Penrosian view. [12] Innovation is investigated by various models and approaches through theoretical positions, including institutional theory, cognitive theories, transaction cost economics, socio-technical approaches, market orientation (MO) and resource-based views.[44] In this regard, it is possible to say that the new-economy organizations comply more with the Schumpeterian view.

\subsubsection{Knowledge Management as a Strategic Tool}

Previous studies have derived a multiplicity of approaches to implement strategies on KM. As the market conditions continuously vary, increasing pressure of competition and customers' expectations begin to define knowledge as a factor that provides a strategic competitive advantage [5]. Knowledge-based strategies today depend on the success of a business, mostly on organizational competencies or improvement of operational performance. [66]

In today's economic environment, organizations are required to create differentiable value by establishing a certain synergy between strategy and innovation. Enhancing the innovative ability in organizations is one of the most important levers for increasing profitability and growth in organizations.[49] Despite the fact that knowledge has a great importance in most service sectors, different use of knowledge, technology and intensity require sectoral classifications. On the basis of $R \& D$ intensity in sectors, four different sectoral groups are defined by OECD: High technology, medium -high technology, medium-low technology and low-tech. The high-tech and medium-high-tech sectors are considered to be "knowledge-based industry sectors". Among these sectors, knowledge-intensive service sectors, such as health care, banking, insurance, consulting and training industries, occupy an important place. [67] 


\subsection{The Emerging Role of Knowledge Professionals in Innovation}

The knowledge economy suggests the development of human resources with new roles, skills and competencies. Organizations must be able to transform human resources into knowledge-oriented employees and manage them to ensure a competitive advantage. In this context, knowledge professionals form the organization's intellectual capital in line with the business strategy [68]. The increasing importance of knowledge and the rapid increase of information require the lifelong learning needs of knowledge professionals. 1691 Therefore, knowledge professionals should possess a creative and innovative perspective in all areas of business. Organizations need human power that can demonstrate the skills of discovery, experimentation and development of new technologies, products and/or services, processes and organizational structures. Many companies take into account the fact that new technologies and management approaches are changing the traditional perspective of managing intellectual resources. [70]

A critical question might be as "What is the role of knowledge professionals in the innovation process?". Although knowledge professionals are major players in the innovation process, they are also influential in the way how they perform their role as decision makers. They must carry out important roles and be supported by top level management. [3]

\subsubsection{Knowledge Professionals as Decision Makers}

Both manufacturing and other services are increasingly encouraging particular business services to perfom a number of tasks related to innovation. This, in turn, leads an ongoing redistribution of knowledge from traditional producers and service providers.[71] Knowledge professionals are experts who design systems necessary for organization, including roles of knowledge gathering, organization and storage. They also transmit the knowledge to any organization. [72] Knowledge professionals may come from different disciplines, such as information and communication technology specialists, public relations professionals, human resource professionals, psychologists or neurologists. [73]

The literature presents similar statements with regard to the emerging role of knowledge specialists. Freel (2006) identified factors like innovation expenditure and output, innovation networking and knowledge intensity; these were defined as success factors that vary between sectors. [74] In his study, İraz (2005) addressed knowledge related to strategic decisions. [3] According to the study, developing modern information technologies, empowering relationships with knowledge workers and investing within the knowledge are important strategic decisions. According to İraz (2005), there are some critical factors related to professional experience of knowledge workers, such as trainina knowledqe workers and the identification of personal goals associated with targeted objectives. [3] According to Huffman (1990), the development of each knowledge worker has its own dynamics; this is related with personal objectives. In this respect, leaders have to support the developmental process of knowledge and encourage the knowledge workers, strategists, engineers, technicians and researchers who act in this process. [75] [70]

\subsubsection{The Skills of Knowledge Professionals in Innovation}

Advances in digital economy enforce the organizations ability to employ more skilled labor with different competencies and capabilities. In this sense, the role of the human factor and areas of responsibility have significantly changed. During this process, it is important that the organizations believe that their management approach and culture are based on knowledge, with professionals as the key users. [76]

Knowledge professionals are involved in all phases of knowledge management, as they are the maior actors in the knowledge management team. It is important for these experts to collaborate, communicate and convert explicit knowledge in many areas if the right decisions are to be made. For this reason, knowledge professionals need to manage knowledge and be qualified for the needs of the century that is known as "Knowledge Economy". Iraz (2005) states that knowledge workers are influenced by personal traits and demographic factors linked to education level, attitudes, and values within the process of innovation and creativity. 131 Additionally, their innovation capabilities are important factors that will contribute significantly in business innovation that in tum supports their efforts to identify and personalize. In a different study, Tavakoli and Lawton (2005) summarize the roles of knowledge managers as; [77]

- To res earch, create, share and use knowledge in daily activities,

- To create the background for information-oriented activities, manage knowledge professionals, achieve effective results with efficient use of time and mental resources,

- To share knowledge and integrate the work with knowledge professionals.

A typical knowledge worker is capable of managing teams of people like archivists, data analysts, data processors, librarians and reporting specialists. In many organizations, each professional who works as a manager in any field has their own area of expertise in knowledge management. When considered in tems of upper management, certain professionals need to have technical know-how, skills and experience. A professional, in addition to doing his job correctly, has to increase yield, be able to use methods and techniques, access knowledge, evaluate it and share it with the organization's other employees. [76]

Knowledge managers must undertake different roles as:

1. Information Manager (CKO-Chief Knowledge Officer): they must make every kind of knowledge value easily and effectively accessible for other employees. 
2. Technology Officer (CTO-Chief Technology Officer): they must be aware of the potential of IT and must create an effective IT strategy.

3. Asset Manager (CAO-Chief Asset Officer): in order to obtain the best possible performance of these technologies, they need to be positioned in the right areas [78]

Skyrme (2000) highlighted that each knowledge manager is a knowledge leader and their main role is to create and develop every network for knowledge sources, including individual skills, learning and knowledge. [79] However, the digitization of institutions creates a great challenge that requires leadership in knowledge-based applications by which emplovees can achieve their goals. The results of an empirical study conducted in Canada reveals that knowledge professionals should have the following skills such as; communication skills, leadership skills, facilitation skills, networking skills, negotiating skills, consensus building skills, persuasion skills, team working, coaching skills as well as mentoring skills. [80]

In an institution, inculcating a culture of teamwork is particularly important for an effective management of knowledge and to create a knowledge organization. In relation to the research above, if the aim is to create a team intended for business process and leadership, then it should not be surprising that knowledge professonials should have skills in teamwork. Thus, Tiwana (2003) indicates some basic characteristics that knowledge managers should have to carry out during performing some tasks as illustrated in Table 2. [81]

Table 2. Knowledge Professionals 'Typology

\begin{tabular}{|c|c|}
\hline Characteristics of Knowledge Professionals & Skills of Knowledge Professionals \\
\hline Understanding the process of working in the field & Search for new ways to access, \\
\hline Being adept at interpers onal and team relationships & Ability to follow new technologies, \\
\hline Being reliable at a certain level & Being user-centered \\
\hline $\begin{array}{l}\text { Being willing to see through different functional } \\
\text { perspectives }\end{array}$ & $\begin{array}{l}\text { Editing library services according to the } \\
\text { demands of technology and users with } \\
\text { expectations, }\end{array}$ \\
\hline Being thoroughly familiar with technology & Ability to share knowledge with colleagues \\
\hline $\begin{array}{l}\text { Being willing to understand the perspectives of the } \\
\text { other team members and including these in the } \\
\text { project design }\end{array}$ & zing information sources \\
\hline Being willing to learn & \\
\hline Having a comprehensive customer orientation & \\
\hline $\begin{array}{l}\text { Being familiar with the management and strategic } \\
\text { processes }\end{array}$ & \\
\hline Completely believing in the value of the project & \\
\hline
\end{tabular}

As summarized above, it is critical for knowledge professionals to have technical knowledge and experience. For instance, the employee in charge of the archives has to be aware of the classification, evaluation and selection of the documents. For a data analyst, it is fundamental to know the definition of concepts such as knowledge ontology and metadata. These are essential for all knowledge professionals who are responsible for managing knowledge.

In addition to knowledge professionals, comorations also have to keep pace with the changes, develop new alignment methods and forms of work. This renewal is also valid for other organizations. Governments have begun taking steps towards making the necessary changes in state policies and action plans. For example, in Turkey, the Ministry of Education (MEB) has conducted may projects with the aim of becoming a knowledge society. In the 2010 -2014 strategic plan of the Ministry of Education, Lifelong Learning and Information Society Project technology literacy was mentioned. Furthermore, the information technology (IT) classes in schools were launched for the use of every citizen. The Public Internet Access Points (PIAP) projects aims at making schools the center of technology and development with the intent to improve citizens' access to information, giving media literacy education in schools and increasing the rate of IT literates by $10 \%$ every year $[82]$

\section{THE INNOVATION PERSPECTIVE IN TURKEY THROUGH KNOWLEDGE MANAGEMENT}

One of the most important steps for benefiting from the knowledge economy is to establish a comprehensive network of information systems. [70] In addition to traditional tasks stated in previous section, new roles are added for knowledge professionals, such as network information, information technology, multi-media, creation of e-documents, electronic databases, web site/ page editing, Web 2.0, Web containing 3.0 or even Web 4.0 applications. [73] As Goethals et al 
(2004) suggest, knowledge society is marked by rapid and far-reaching technological changes in ICTs fostered by accelerated globalization. [83] This shift has moved knowledge towards the major factor of production. [84]

Knowledge-Intensive Business Services (KIBS) are increasingly recognized as creative innovators that occupy a dynamic and central position in new knowledge-based economies. This recognition, in turn, has recently stimulated significant research in the field [85]

In the literature, various perspectives associating knowledge with innovation have appeared, such as knowledge-based firm perspective [86] [85] [87] [71]; knowledge-intensive business services [88] [89] [90] [91] [74] [92]; innovation performance [931 knowledge diversity [941, knowledge sharing [95] and creation [96] [97] [98], knowledge transfer [99] innovation [100] [101] [102] [103] [104] and economic view. [105]

\subsection{The Developments in Knowledge- Based Innovation in Turkey}

In Turkey, there have been recent developments in the field of $\mathrm{KM}$ and innovation, primarily in public services. The most important one has been the establishment of the Executive Board "e-transformation in 2003" and the latest investments made in the "e-Turkey project". Electronic transition firstly began as the establishment of a new democratic and transparent management approach which focused on accelerating the business and operations between government institutions and its citizens. Another development is the "Law on Electronic Signature" in 2004, which allowed the production of records in the electronic environment to be leqally and technologically possible.[106] Records approved with electronic signature have the same authority as those signed by hand. This approval allows work and operations being moved to electronic environment. Another development is the regulation of "TSE 13298 Electronic Records Management Standard" the preparations of which began in 2005, later becoming a standard in 2007. This standard enabled public institutions and organizations to produce electronically generated records in a standard way.

Records are the essential tools that help comorations to demonstrate their activities, business and operations. Corporations can send records to one another in hundreds of formats. The Ministry of Development announced another project which restricted formats used in the public sector with a circular for institutions. This project comprises principles of interoperability which can be used for determining data formats used for sharing information, documents or records between institutions.[107]

Furthermore, records have a strong evidential characteristic as a knowledge asset which is used for performing the institutional functions. However, it is important for the life cycle of records to be aware of which institution they are produced by. That is why the head of the Administrative Development Department classified every public institution and organization in a central database. Each were given an unchangeable code. This project is known as the State Agency Database. [108] Institutions that are producing records or units that are operating for them hierarchically were entered into a single central database.

This provides the basis for sharing records between institutions, facilitating the procedure for sending records defined in the e-mailing package. The e-mailing package describes technically how to send documents to the partner institution by the Registered Electronic Mail System (KEP) with a zip file that includes the attachments, electronic signature and metadata.[107]

One of the main obiectives of all the proiects is to provide high quality and uninterrupted public services to the citizens in the electronic environment. Nevertheless, in Turkey, records management project are still an ongoing process. Particularly for local governments, it is very difficult and expensive to establish, operate and manage an Electronic Records Management System that is efficiently integrated with the e-government. With the e-Turkey Cloud Computing activities, it will be possible for local institutions to conduct the necessary investments.

\subsection{Knowledge Assets, Governance and Government}

Governance is a form of management style, whereas government is about managing institutions and organizations that are responsible for the act of managing itself. [109] Government, democratic or autocratic, is responsible to the people who demand good governance. Government, in this sense, is directly responsible for the performance of public institutions and indirectly responsible for the performance of private organizations within the laws and regulations. For this purpose, it can be implied that governance is more than a structure on a paper. It is a structure that contains the dynamic human movements which require governments to search for solutions for the problems and needs of the citizens. While doing this, a mutual interaction and a consideration of the balance of supply and demand is necessary. At this point, the impact of the management and the transformation of the concept of governance is unescapable. Citizen-focused activities continue, regardless of cost and can be considered as an indicator of accountability and transparency in a reliable government.

The factors mentioned above address a complex and surprising link between governance and management. Jessop (1998) points out that governance has a pre-theory and eclectic background. [109] Sternberg (1998) mentions that there is a sharp contrast between institutional governance and qovernment. $[1101 \mathrm{He}$ arques that qovernance is supported by the forceful power of the government and gets this power by legitimizing its public policies and goals with the people. Compared to government, less powered private corporations are only respons ible towards their shareholders. But they still must obey the rules and legal requirements of the government. The most important move in democracy for governments is to improve the corporate governance by gaining the confidence and support of the people. The corporate governance should be matured with an open structure. At this point, the records and the evidence contained in the records becomes a mirror of the governance, encouraging the creation of a trusty environment. Thus, accountability and transparency can be 
verified through records and this acts as an indicator of good governance. Creation and archiving of records on a regular basis does not only show good governance, but also prevents the hiding of bad governance. "National Judicial Network Project (UYAP)", installed by the Ministry of Justice in 2000 , aims to provide public prosecutors, law enforcement departments and other units with effective and faster communication. Thus, easy and rapid access to infomation will help to provide integration with other institutions and organizations while the judging process will be shortened significantly. [111]

The e-government system also focuses on providing citizens with government transactions that can be easily and securely accessible over the internet. [112]. Similarly, the case of "e-school" is an important proiect for creating a portal in the education system, allowing parents to acquire comprehensive information about the students. Parents who want to be informed of the status of a student can use the system by providing the student's information; thus, they can be informed of the student's school attendance and lesson perfomance. [113]

Another important development in Turkey is the establishment of the "Science and Technology Council" (SCST)", launched in 1983, which provides better use of information systems. Apart from SCST, there are other complementary institutions like BILLTEN, the Council of the Internet, public-net Supreme Council, Electronic Commerce Coordinating Council, and many other associations and foundations (TBD, TIF, etc.). [114]

When the public applications are considered in Turkey, other ongoing projects on information systems application include: Mernis, Mebsis, TAKBIS, VEDOP I and VEDOP II, Issue 2000 Project, Farm-Net, Farmer Registration System, UYAP I and UYAP II, Polnet, GÜMSIS, Gouache E-Statement, BeOS and audio.

Most of the time physical records have proved that the efficiency and effectiveness of public administration are critical for affective $\mathrm{KM}$, as they have become a part of the public administration. However, evolving technology demonstrates that physical records are under inadequate conditions to become part of the government. The changes in the areas of Information and Communication have led records management, and related to that, the activities are today observed as evidence of governance, to become automatic and transferred to electronic environment. While physical records are part of management, electronically generated records have either become part of both management and governance. The benefits of Information and Communication Technologies are the easy storage of records and information, and rapid access. In contrast, new and critical problems have begun to occur, such as ensuring the accuracy of the records, as well as the protection and the long-term management of records. The authenticity and reliability of electronic documents is an issue that needs to be carefully organized. Trying to establish a transparent governance and management structure by transferring records management to an electronic environment without care, in a disorganized and uncontrolled manner will be unsuccessful. Instead, by building a model based on business and/or procedures, it is expected that the originality and the security of the electronic records can be guaranteed. This will also increase the ability to work with non-electronic systems. So that, the government may take steps towards producing records in a secure and reliable way, as well managing and saving them in the electronic environment under difficult circums tance [115].

\section{CONCLUSION AND FURTHER DISCUSSION}

The effects of developments in computer and communications technology have changed the way the rapid changes in terms of changing innovation and creativity are dealt with. Global competition has led to the em ergence of knowledge as a strategic asset, in addition to traditional factors of production. The last decade has been marked by concepts like knowledge society or economy, representing an era that has experienced rapid economic, political, cultural, legal and social changes. These changes lead to the production of more knowledge. In parallel with these developments, intensive technological changes can also be seen. Knowledge and technology are two inseparable factors that help efficient KM. A way to become a knowledge society depends on the knowledge and technology used in the society and institutions.

In fact, as knowledge has become one of the core assets of companies, the economy in recent years has been demonstrating progress towards becoming a knowledge-based economy. The new economic order has brought new concepts to the system, replacing the traditional and hierarchical order, by enhancing information sharing; indeed, this is considered to be the most important factor of production. The widespread adoption of advances in information technology and automation continues to increase intense competition in global markets. As a result of increased competition, local corporations are forced to operate across borders and chase new opportunities to compete with the world economy. This is valid for knowledge-based organizations in the Information Society. In this regard, the production of knowledge, technology and the conversion of data produced are intended to capture a significant competitive advantage in technological as pects.

Most corporations have difficulties in managing knowledge. At the heart of such difficulties lie the imperfect definition of knowledge in the organization and the inability to measure the intellectual assets. The most important reas on for this is the need for innovation as a strategy in all sorts of knowledge management activities. It brings new trends and applications. Depending on these developments, organizations should follow up the trends and make the necessary changes. The innovative efforts are critical for rational investment in knowledge. If $\mathrm{KM}$ is positively influenced by the search for innovations, the investments in the development of new knowledge may propel companies into new businesses in more rewarding markets. This will also help to improve the skills of the knowledge professionals. Innovative efforts have to be strategically combined with a competitive orientation and its consequent movements. This combination depends on the highest level of individual knowledge and on its technological basis.

The hamonization of innovation with the skills of knowledge professionals is vital for the organization. Within this process , knowledge professionals have important roles and responsibilities to mentor and manage business processes effectively. 
Because their main interest area is information and technology based, the steps to create new information, to access information and the evaluation of it have to be taken by knowledge professionals. This mechanism also has to be supported by governance mechanisms.

\section{REFERENCES}

[1] Alavi, M. and Leidner, D. E. (2001). Knowledge Management And Knowledge Management Systems: Conceptual Foundations And Research Issues", MIS Quarterly, Vol.25, pp.107-136.

[2] İnce, M., and Oktay, E.(2006).Bilginin Bir Stratejik Güç Olarak Önemi Ve Örgütlerde Bilgi Yönetimi, Selçuk Üniversitesi Karaman IïBF Dergisi, Sayı 10, Yıl 9, Haziran.

[3] İraz, R. (2005). İşletmelerde Bilgi Yönetiminin Yenilik Ve Rekabet Gücü Üzerindeki Etkileri, Iktisadi Ve İdari Bilimler Dergisi, Cilt: 19, Nisan, Sayı: 1, pp. 243-258.

[4] Cetin, C. and Karabay, M.E. (2010). An Empirical Investigation Through The Efficient Usage Of Knowledge In Turkish Banking Sector, Gazi Üniversitesi İktisadi Ve İdari Bilimler Fakültesi Dergisi, Vol.12, No. 2, pp.27-56.

[5] Karabay, M. (2010). Bilgi Ekonomisine Geçiş Sürecinde Finansal Piyasalarda Stratejik Rekabet Olgusu: Bankacılık Sektörü Üzerine Bir Uygulama, Marmara Üniversitesi, Bankacılık ve Sigortacılık Enstitüs ü, Yayımlanmam ı̧ Doktora Tezi, İstanbul.

[6] Liebowitz, J., Suen, C.Y. (2000). "Developing Knowledge Management Metrics For Measuring Intellectual Capital”, Journal of Intellectual Capital, Vol 1, No:1, pp.54-67.

[7] Robert, K. (2005). "Knowledge for Future Competitive Advantage”, Acing Today, June, pp. 20-21.

[8] Oort, F.V., Raspe, O. (2005). "The Knowledge Economy and the Dutch Cities", European Regional Science Conference, pp.5, Amsterdam.

[9] Ulusahin, A.U. (2005). BDDK Denetim ve Gözetim Amaçıı Veri Tabanı ve Bilgi Yönetimi”, Uluslar arası Finans Sempozyumu, Marmara Üniversitesi B.S.Y.O ve B.S.E , 9-10 Haziran, Istanbul, (2005).

[10] Kumral, N. (2008). Bölgesel Rekabet Gücünü Arttırmaya Dayalı Politikalar, Working Paper, pp.9-10.

[11] Shaikh, J.M. (2004). "Measuring and Reporting of Intellectual Capital Performance Analysis", The Journal of American Academy of Business, Cambridge, Vol.4, No.1/2, March, pp.439-448.

[12] Aykın, H. (2002). "Yeni Ekonomide Devletin Yönü: E- Devlet”, Maliye Dergisi, Vol.141, pp.3-20.

[13] TBB (Türkiye Bankalar Birliği) (2002). Şeffaflığın Önemi Üzerine Bir Değerlendime, Ocak, 3-4 . Türkiye Bankalar Birliği Bankacılık ve Araştırma Grubu.

[14] Goh, A. (2004). "Enhancing Organisational Performance Through Knowledge Innovation: A Proposed Strategic Management Framework", Journal of Knowledge Management Practice, Vol. 5, No. 1, pp.111-123.

[15] Polanyi, M. (1966). The Tacit Dimension, Doubleday and Co: Garden City, NY.

[16] Dhanaraj, C., Lyles, M.A., Steensma, H.K., and Tihany, L. (2004). Managing tacit and explicit knowledge transfer in IJVs: the role of relational embeddedness and the impact on performance, Journal of International Business Studies, No.35, pp.428-442.

[17] Kothuri, S. (2002). "Knowledge in Organizations", May, pp.2-4.[cited; Available from: gseweb.harvard.edu

[18] Silvi, R. and Cuganesan, S. (2006). Investigating The Management Of Knowledge For Competitive Advantage A Strategic Cost Management Pers pective", Journal of Intellectual Capital,Vol. 7, No. 3, pp.309-323.

[19] Perez, J.R. and de Pablos, P.O. (2003). "Knowledge Management And Organizational Competitiveness: A Framework For Human Capital Analysis", Journal of Knowledge Management, Vol: No.7, pp.82-91.

[20] DeTienne, K. B. and Jackson, L.A. (2001). "Knowledge Management: Understanding Theory And Developing Strategy",Competitiveness Review,Vol:11, No:1, pp.1-11.

[21] Li, S.T. and Tsai, M.H. (2008). A Dynamic Taxonomy For Managing Knowledge Assets", Technovation, Vol. 29, No.4, pp.284-298.

[22] Ahuja, G. and Lampert, C.M. (2001), "Entrepreneurship in the large corporation: a longitudinal study of how established fims create breakthrough inventions", Strategic Management Journal, Vol. 22, pp. 521-43.

[23] Tsou, H.T. (2012), Collaboration competency and partner match for e-service product innovation through knowledge integration mechanisms", Journal of Service Management, Vol. 23i Iss: 5 pp. $640-663$.

[24] Luo, G., Wang, Y., Bian, W., \& Lin, S. (2014). Analysis of the interaction between enterprise knowledge innovation and talent management. Advances in Services Science and Services Information Technology (Set), 52, 153.

[25] Stiglitz, J. E. (2014). Intellectual property rights, the pool of knowledge, and innovation (No. w20014). National Bureau of Economic Research. 


\section{ISSN 2321-1091}

[26] Wang, Z., \& Wang, N. (2012). Knowledge sharing, innovation and firm performance. Expert systems with applications, 39(10), pp. 8899-8908.

[27] Taherparvar, N., Esmaeilpour, R., \& Dostar, M. (2014). Customer knowledqe manaqement, innovation capability and business perfomance: a case study of the banking industry. Journal of Knowledge Management, 18(3), 591 -610.

[28] Nonako ,I. and Takeuchi, H.,(1995).The Knowledge Creating Company:How Japaneese Companies Create The Dynamics of Innovation, Oxford University Press Inc., ISBN;0-19-509269-4, Newyork.

[29] Nonaka, I. (1994), "Dynamic theory of organizational knowledge creation”, Organization Science, Vol. 5 No. 1, pp. 14 37.

[30] Fleming, L., Chen, D. and Mingo, S. (2007), "Collaborative brokerage, generative creativity, and creative success", Administration Science Quarterly, Vol. 52, pp. 443-75.

[31] Çeliktaş, H. (2008). İnovasyon Yönetimi: Çukurova Bölgesinde Faaliyet Gösteren Şirketlerde İnovasyon Uygulamalarının Tespitine Yönelik Bir Araştırma", Unpublished Dissertation, Adana: Çukurova Üniversitesi SBE.

[32] Tidd, J. (2001). Innovation Management in Context: Environment, Organization And Performance, International Journal of Management Reviews, Vol.3, No.3, pp.169-183.

[33] Elçi, Ş., Karataylı, İ., Karaata, S. (2008). Bölgesel İnovasyon Merkezleri: Türkiye İçin Bir Model Önerisi, Yayın No. TÜSIAD-T/2008-12/477.

[34] Dougherty D. (1992). A practice-centered model of organizational renewal through product innovation. Strategic Management Joumal, Summer Special Issue 13, pp.77-92.

[35] Bowen HK, Clark KB, Holloway CA, Wheelwright SC. (1994) Development projects: the engine of renewal.Harvard Business Review Vol.72, No.5, pp.110-120.

[36] Danneels, E. (2002). The Dynamics Of Product Innovation And Firm Competences, Strategic Management Joumal, Vol. 23, pp.1095-1121.

[37] Bonanno, G. and Haworth, B. (1998). Intensity of competition and the choice between product and process innovation, International Journal of Indus trial Organization, Vol.16, pp.495-510.

[38] Çalıpınar, H.and Baç, U. (2007). Kobi'lerde İnovasyon Yapmayı Etkileyen Faktörler ve Bir Alan Araştırması, Ege Akademik Bakış , Vol.7, No. 2, pp.445-458.

[39] TÜSIAD. İnovasyon Sistemi, Kavramsal Çerçeve, Türkiye İncelemesi ve Ülke Örnekleri, Araştırma Raporu, Yayın No. TÜSIAD-T/2003/10/362, Ekim, (2003).

[40] Van de Ven, A.H. (1986). Central Problems in the Management of Innovation, Management Science, Vol. 32, No.5, pp.590-607.

[41] Yavuz, Ç. (2010). İşletmelerde İnovasyon-Perfomans İlişkisinin İncelenmesine Dönük Bir Çalışma, Girişimcilik ve Kalkınma Dergisi, Vol.5, No.2, pp.143-173.

[42] Gadrey, J., Gallou, F., Weinstein, O. (1995).New Modes Of Innovation: How Services Benefit Industry, International Journal of Service Industry Management, Vol.6, No.3, pp, 4-16.

[43] Kiernan, M.J.(1996). Get Innovative or Get Dead. Business Quarterly, Autumn, pp.51 -58.

[44] Lawson, B. and Samson, D. (2001). Developıng Innovation Capabılıty In Organizations: A Dynamic Capabilities Approach, International Journal of Innovation Management, Vol. 5, No. 3, pp.377-400.

[45] Gürdal, K. (2004). "Yeni Ekonomi Kavramı ve Yeni Muhasebe Anlayışı”, Muhasebe ve Denetime Bakış Dergisi, Eylül, pp.87-110.

[46] Zack, M. (2000). Competing on Knowledge, Handbook of Business Strategy, pp.81-83.

[47] Barışık, S. and Yirmibeşçik, O. (2006). "Türkiye'de Yeni Ekonominin Oluşum Sürecini Hızandımaya Yönelik Uyum Çalışmaları", ZKÜ Sosyal Bilimler Dergisi, Vol. 2, No. 4, pp.39-62.

[48] Yumuşak, I.G. and Özqür A.(2007). Yeni Ekonominin İktisadi Etkileri ve İktisat Politikası Üzerine Yansımaları, Bilgi Ekonomisi ve Yönetim Dergisi [Elektronic Version], Vol. 2, No.2, pp.18-55.

[49] Satı, E. Z ., Ö. Işık. (2011). İnovasyon ve Stratejik Yönetim Sinerjisi: Stratejik İnovasyon. CBÜ Sosyal Bilimler Dergisi, Vol. 9, No.2, pp. 538-559.

[50] Du Plessis, Marina. (2007). "The role of knowledge management in innovation." Journal of knowledge management $11.4,20-29$.

[51] Darroch,J. (2005). "Knowledge management, innovation and fim performance", Journal of Knowledge Management, 9 (3), pp. $101-115$

[52] Anand, N., Gardner, H. K., \& Morris, T. (2007). Knowledge-based innovation: Emergence and embedding of new practice areas in management consulting fims. Academy of Management Journal, 50(2), 406-428. 
[53] Zhang, H., Shu, C., Jiang, X., \& Malter, A. J. (2010). Managing knowledge for innovation: the role of cooperation, competition, and alliance nationality. Journal of International Marketing, 18(4), $74-94$.

[54] Vaz, T. D. N., \& Niikamp, P. (2009). Knowledqe and innovation: The strings between global and local dimensions of sustainable growth. Entrepreneurship and Regional Development, 21(4), 441-455.

[55] Brusoni, S., Marsili, O., \& Salter, A. (2005). The role of codified sources of knowledge in innovation: Empirical evidence from Dutch manufacturing. Joumal of Evolutionary Economics, 15(2), $211-231$.

[56] Kavrakoğlu, İ. (2006). İnovasyon, 1. Baskı, Alteo Yayıncılık, Istanbul.

[57] Gopalakrishnan, S. and Bierly, P. (2001).Analyzing Innovation Adoption Using A Knowledge-Based Approach", Journal of Engineering and Technology Management, Vol.18, pp.107-130.

[58] Havens, C. and Knapp, E. (1999. Easing Into Knowledge Management”, Strategy \& Leadership; Vol.27, No: 2, pp.4 -9.

[59] Fitchett, J. (1998). Managing Your Organization's Key Asset: Knowledge", The Healthcare Forum Journal, Vol. 41, No.3, pp.56-60.

[60] Jordan, J. (1997). Competing Through Knowledge: An Introduction”, Technology Analysis \& Strategic Management, Vol.9, No 4, pp.379-381.

[61] Sharkie, R. (2003). Knowledge Creation And Its Place In The Development Of Sustainable Competitive Advantage", Journal of Knowledge Management, Vol.7, No:1, pp.20-31.

[62] Kridan, A.B. and Goulding, J.S. (2006). "A Case Study On Knowledge Management Implementation In The Banking Sector", The Journal Of Information And Knowledge Management Systems,Vol.36, No.2, pp.211-222.

[63] Chan,I. and Au, A.K. (2008). "Knowledge Creation - Presumption Versus Actual Practice", Contemporary Management Research, Vol. 4, No. 2, pp. 105-118.

[64] Hamel, G. and Prahalad, C.K. (1990). "The Core Competence Of The Corporation", Harvard Business Review, www.hbr.org Online (16.09.2008)

[65] Schumpeter, J. (1934). Theory of Economic Development. An Inquiry Into Profits, Capital, Credit, Interest, and the Business Cycle. Cambridge: Harvard University Press.

[66] Grant, K. and Grant, C. (2005). The Knowledge Management Capabilities of the Major Canadian Financial Institutions, International Conference on Knowledge Management (ICKM), Malaysia, http://ickm.upm.edu.my/presenter4.html (16.04.2013)

[67] Saygılı, Ş. (2003). "Bilgi Ekonomisine Geçiş Sürecinde Türkiye’nin Dünyadaki Konumu”, DPT, No: 2675, pp.5-6.

[68] Lengnick,L. M., Lengnick, A., C., (2004). Bilgi Ekonomisinde İnsan Kaynakları Yönetimi, Çev.Günay, Günhan, Dışbank Kitapları, Sayı:.7, 1.Basım, ISBN:975-8296-67-1, İstanbul.

[69] Kurbanoğlu, S. (2004). Öz-Yeterlik İnancı ve Bilgi Profesyonelleri İçin Önemi(Self-Efficacy Belief and Its Importance for Information Professionals)", Bilgi Dünyası, 5(2), pp. 137-152.

[70] Carneiro, A. (2000). "How Does Knowledge Management Influnce Innovation and Competitiveness?", Journal of Knowledge Management, Volume 4, Number 2, pp.87-98.

[71] Tether, B. and Hipp, C. (2002). Knowledge intensive, technical and other services: patterns of competitiveness and innovation compared, Technology Analys is and Strategic Management, 14, pp. 163-182.

[72] Özer,M.A. (2011). Bilginin Yolculuğunda Bilgi Çalışanlarının Rolü, Çimento Endüstrisi İşverenleri Sendikası Yayını, Mayıs, pp. 4-20.

[73] Ramzan, M. (2004). Effects of IT utilization and knowledge on librarians' IT attitudes. The Electronic Library, 22(5), pp. 440-447.

[74] Freel, M. (2006). Patterns of Technological Innovation in Knowledge-Intensive Business Services, Industry and Innovation, 13:3, pp. 335-358.

[75] Huffman, C.D., Loken, B. and Ward, J. (1990). Knowledge and context effects on typicality and attitude judgements", Advances in Consumer Research, Vol. 17, pp. 355-60.

[76] Bayraktar, Bir, B. (2007). 21.yy Bilgi Yöneticisi: Özellikleri, Rol ve Becerileri,Yetkinlikleri ve Alışkanlıkları”, Beta Yayınları, 1. Baskı, ISBN 978-975-295-791-6, İstanbul.

[77] Tavakoli, I. and Lawton, J. "Strategic Thinking and Knowledge Management", Handbook of Business Strategy, Emerald Group Publishing Limited. (2005).

[78] Yodokawa, K. (2000). The CIO As The Drving Force Behind IT Restructuring", Nomura Research Institute (NRI) Papers, No.7 http://www.nri.co.jp/english/opinion/papers/2000/pdf/np200007.pdf, [ Retrieved: 23.08.2013]

[79] Skyrme, D. (2000). "Developing a Knowledge Strategy: from Management to Leadership"., Cited in Morey, D. and Thuraisingham, B. (Eds) Knowledge Management. Classic and Contemporary Works. MIT Press. Cambridge, MA. 
Cited in Viitala, R. (2004) Towards Knowledge Leadership. The Leadership \& Organization Development Joumal, Vol. 25, No. 6, Emerald Group Publishing Limited., U.S.A.

[80] Aiiferuke, I.(2003). "Role of Information Professionals in Knowledge Management Programs: Empirical Evidence from Canada", Informing Science, Joumal Information Science, Volume 6 (The original version of this paper was published as one of the 24 "best" papers in the proceedings of the 2003 Informing Science and IT Education Conference in Pori, Finland http://2003.insite.nu)

[81] Tiwana, A. (2003). Bilginin Yönetimi, bilgiprofesyonellerinin, dijitalÇev. Elif Özsayar, Dışbank Kitapları-5, 1. Basım, ISBN:975-8296-49-3, İstanbul.

[82] Çakır, R. and Oktay, S. (2013). Bilgi Toplumu Olma Yolunda Öğretmenlerin Teknoloji Kullanımları”, Gazi Üniversitesi Endüstriyel Sanatlar Eğitim Fakültesi Dergisi, No. 30, Ankara, pp.35-54.

[83] Goethals, G. R., Sorenson, G., Burns, MacGregor, J. (2004). "Leadership in the Digital Age" The Encyclopedia of Leadership, SAGE

[84] Howells, J. (2000). Innovation and Services: New Conceptual Frameworks, CRIC Discussion Paper 38 (Manchester: University of Manchester).

[85] Wong, P. K. and He, Z.-L. (2005). A comparative study of innovative behaviour in Singapore's KIBS and manufacturing fims, Service Industries Journal, 25, pp. 23-42.

[86] Tödtling, F., Skokan, K., Höglinger, C., Rumpel, P., \& Grillitsch, M. (2013). Innovation and knowledge sourcing of modern sectors in old industrial regions: comparing software firms in Moravia-Silesia and Upper Austria. European Urban and Regional Studies, 20(2), 188-205.

[87] Martín-de Castro, G., López-Sáez,P., and Delgado-Verde,M. (2011). Towards a knowledge-based view of fim innovation. Theory and empirical research , Journal of Knowledge Management, 15(6), pp.871-874.

[88] Doloreux, D., Freel, M. and Shearmur, R.(2010). Exploring and Comparing Innovation Patterns across Different Knowledge Intensive Business Services. Economics of Innovation and New Technology, 19(7), pp. 605-625.

[89] Martinez-Fernandez, C. (2010). Knowledge-intensive service activities in thesuccess of the Australian mining industry, Service Industries Joumal, 30(1), pp. 55-70.

[90] Amara, N., Landry, R.J., \& Doloreux, D. (2009). Patterns of innovation inknowledge-intensive business services. The Service Industries Journal, 29(4), 407-430.

[91] Whittington, K. B., Owen-Smith, J., \& Powell, W. W. (2009). Networks, propinquity, and innovation in knowledgeintensive indus tries. Adminis trative science quarterly, 54(1), 90-122.

[92] Den Hertog, P. (2000). Knowledge-Intensive Business Services as Co-Producers of Innovation, International Journal of Innovation Management, 4, pp. 491-528.

[93] Wastyn, A.\& Czarnitzki, D., (2010) Does Professıonal Knowledge Management Improve Innovatıon Performance At The FIrm Level? Paper to be presented at the Summer Conference 2010 on "Opening Up Innovation: Strategy, Organization and Technology" at Imperial College London Business School, June 16 - 18.

[94] Dell'Era C., Verganti R., (2010). Collaborative Strategies in Design-Intensive Industries: Knowledge Diversity and Innovation. Long Range Planning, Vol. 43, pp. 123-141.

[95] Kimble,C.,Grenier,C., and Goglio-Primard, K. (2010). Innovation and knowledge sharing across professional boundaries: Political interplav between objectsand brokers. International Journal of Information Management, 30(5), pp. 437 - 444.

[96] Mahr, D., and Lievens,A. (2012). Virtual lead user communities: Drivers of knowledge creation for innovation, Research policy, volume: 41, Issue: 1, pp.167-177,

[97] Von Krogh, G., Ichijo K. \& Nonaka, I. (2000). Enabling Knowledge Creation: How to Unlock the Mystery of Tacit Knowledge and Release the Power of Innovation. New York: Oxford University Press.

[98] Porter-O'Grady, T. (2010). Leadership for innovation: from knowledge creation to transfoming healthcare. In:PorterO'Grady T, Malloch K eds. Innovation Leadership: Creating the Landscape of Healthcare. Boston, MA: Jones \& Bartlett.

[99] Weidenfield, A., Williams, A.M and Butler, R. W.(2010). Knowledge transfer andinnovations among tourist attractions, Annuals of Tourism Research, 37(3), pp. 604-626.

[100] Buckley,S., and Jakovljevic,M. (2012). Knowledge management innovations for interdisciplinary education: organizational applications, Hershey PA: Information Science Reference.

[101] Swan, J., Newell,S., and Scarbrough, H. (1999). Knowledge management and innovation: networks and networking , Journal of Knowledge Management, 3, 4, pp.262-275.

[102] Newell, S., Robertson, M. Scarbrough, H. and Swan, J. (2002). Managing Knowledge Work, Palgrave, Basingstoke, Hampshire. 
[103] De la Vega, A. F. R., \& Stankosky, M. (2010). Knowledge management and innovation: What must governments do to increase innovation?. Search of Knowledge Management: Pursuing Primary Principles, 275.

[104] Amalia,M., and Nugroho,Y. (2011). An innovation perspective of knowledge management in a multinational subsidiary", Journal of Knowledge Management, Vol. 15, Iss: 1, pp.71 - 87.

[105] Dubina, I. N., Carayannis, E. G., \& Campbell, D. F. (2012). Creativity economy and a cris is of the economy? Coevolution of knowledge, innovation, and creativity, and of the knowledge economy and knowledge society. Journal of the Knowledge Economy, 3(1), 1-24.

[106] Electronic Signature Law, Turkish Law Number 5070, (2004) Official Gazette number:25355

[107] Ministry of Development, Information Society Department. e-Yazışma Teknik Rehberi (2012). Retrieved from http://www.e-yazisma.gov.tr/SitePages/eyasizmaana.aspx

[108] DTVT, Başbakanlık Devlet Teşkilatı Veri Tabanı Genelgesi (2011). https://www.kaysis.gov.tr/Devlet Teskilat Detsis (01.03.2015)

[109] Jessop, B. (1998). The Rise of Governance and the Risk of Failure: The Case of Economic Development. International Social Science Journal, No.155 (March), pp.29-45.

[110] Sternberg, E. (1998). Corporate governance : accountability in the marketplace. London: Institute of Economic Affairs.

[111] Bezirci, Pervin Dedeler. (2010). Türkiye'de Hukuk Bilgisine Erişim. (Turkish). Accessing Legal Information Sources in Turkey. (English), 11(1), pp.192-218.

[112] Kumaş, E., \& Birgören, B. B. (2010). E-Devlet Kapısı Projesi Bilgi Güvenligi ve Risk Yönetimi: Türkiye Uygulaması. (Turkish). E-Government Gateway Project, Information Security and Risk Management: Turkish Case. (English), 3(2), pp. 29-35.

[113] Bağlıbel, M., Samancıoğlu, Mş., \& Summak, M. S. (2010). Okul yöneticileri tarafından e-okul uygulamasının genişletilmiş teknoloii kabul modeline göre değenlendirilmesi. Assessment of e-okul application by school managers using extented technology acceptance model, 7(13), 331.

[114] Bengshir, K. T. (2000). "Bilgi Toplumu Bakanlığı Mekanik Bir Örgüt mü”, Amme İdaresi Dergisi, Cilt: 33, Eylül, Sayı:3, pp. 33-62.

[115] US-InterPARES Project United States. National Historical, Publications Records, Commission. (2002). Findings on the preservation of authentic electronic records : final report to the National Historical Publications and Records Commission. [Los Angeles, Calif]: US-InterPARES Project.

[116] Ahuja, G. (2000), "The duality of collaboration: inducements and opportunities in the formation of inter-fim linkages", Strategic Management Journal, Vol. 21, No. 3, pp. 317-43. 